\title{
REGISTRATION REQUIREMENTS AFTER REMOVAL OF PROPERTY AND CHOICE OF LAW
}

\author{
DELLAS W. LEE*
}

\begin{abstract}
This article examines briefly the approach courts have taken in awarding priorities under pre-Act (pre-Ontario Personal Property Security Act) law in removal cases and explores the manner in which similar problems will be dealt with under the Ontario Personal Property Security Act.1 The provisions of the Ontario Act are also examined incidentally for their meaning and internal consistency as well as for their potential impact on the pre-Act law of Ontario and indirectly on the laws of other Canadian jurisdictions. The proposed Uniform Personal Property Security Act ${ }^{2}$ recommends only one substantial amendment to the relevant provisions of the Ontario Act and this is commented upon briefly.
\end{abstract}

It is generally conceded that the reasons for requiring registration to perfect a nonpossessory security interest are (1) to permit the secured party to protect himself against future adverse claimants by complying with what might be described as constructive notice requirements, and (2) to permit third parties to protect themselves through a search of the records. ${ }^{3}$ The question remains, however, in which jurisdiction must a secured party register to obtain maximum protection of his security interest in view of the fact that the property is by nature capable of being moved from one registration unit to another by the debtor? Retrospectively the question is, what law should the court apply in resolving conflicting claims to property subject to a security interest created elsewhere, the law of the place in which the secured party obtained his interest and with which he probably complied (first situs), the law of the forum, or perhaps some other law?

Removal problems may arise intra-provincially, by virtue of multiple local or county registration systems within a single province, or interprovincially. With respect to intra-provincial removals, it is obvious that if a secured party is required to register in district $X$ and the collateral is subsequently moved to district $Y$, a search by a prospective buyer or lender in district $Y$ would reveal nothing. Quite naturally the earliest personal property registration systems were patterned after the local filing systems used for real property and perhaps they substantially fulfilled their intended purpose for a few years after their institution. But with the advent of the automobile, which in turn added

- Professor, Faculty of Law, University of Alberta. Grateful acknowledgment is due to Dr. Frank R. Kennedy of the University of Michigan Law School for reading the manuscript and for making numerous valuable suggestions with respect to form and substance.

1 S.0. 1967, c. 73.

2 The proposed Act is being drafted by a committee of the Canadian Bar Association under the chairmanship of Professor Jacob Ziegel of McGill University. A report of the Committee was presented to the 51st Annual Meeting of the Canadian Bar Association in Ottawa, on Sept. 3, 1969.

3 This is not to Imply that registration with respect to security interests taken in personal property does in fact constitute consructive notice in all Canadian jurisdictions. personal property does in fact constitute consructive notice in all Canadian jurisdictions. Registration and constructive notice are discussed elsewhere. Lee, Perfection by Regis-
tration (1969) 47 Can. Bar Rev. 420 $\mathrm{n}$. 18 and 20 , See also Joanes, Third Party Rights in Goods Subject to Conditional Sales Agreements and Chattel Mortgages, 1 U.B.C. L. Rev. 23. at 28-32 (1959): and LaForest. Filing Under the Conditional Sales Acts Is It Notice to Subsequent Purchasers? (1958) 36 Can. Bar Rev. 387. 
to the mobility of vast amounts of other types of personalty, local registration became progressively more inadequate. Although a substantial number of Canadian jurisdictions still adhere to local filing, a movement in the direction of central registration is doing much to eliminate the problems caused by the mobility of personal property under a local registration system.

Removal problems are not about to disappear, however, since from a national perspective the transfer of property from one registration unit to another, across provincial boundaries, precipitates problems virtually identical with those encountered in intra-provincial removals under a local filing system. In either case the secured party can put all potential third parties on notice of his interest only by registering in every district or jurisdiction in the nation, and if third parties wish to guard against all possibilities of outstanding interests in the property with which they propose to deal, theoretically they must search in all districts of every jurisidiction in the nation. Under any system short of national central registration, therefore, removal problems will continue at one level or another. But even with national registration, there remain the further problems arising from the possibility of transportation of property across national boundaries. Accordingly courts have been, and no doubt will continue to be, called upon to resolve conflicting claims to property asserted by innocent parties who, as a practical matter, frequently are unable to protect themselves against unauthorized removal and subsequent fraudulent dispositions by the debtor.

In view of the existence of province-wide central registration in two provinces and the local-central registration systems of three others, including the system contemplated by the Ontario Act, the subject of intra-provincial removals and attendant problems need not detain us long.

\section{I.-INTRA-PROVINCIAL REMOVALS}

\section{Pre-Act Law:}

For more than a hundred years some chattel security states have required filing of a certified copy of the security device in the district to which the goods have been removed within a stipulated period following removal. Even in the earliest statutes this requirement applied generally without regard to the secured party's knowledge of the removal. Consequently there has been little opportunity for the kind of litigation that may arise in the absence of such legislation and no reported cases have been found involving the rights of secured and third parties apart from statute. The only reasonable inference to be drawn, however, is that in the absence of statutory refiling requirements, on common law principles (nemo dat quod non habet) the secured party would prevail over creditors of the debtor and subsequent purchasers and mortgagees without refiling in the district to which the collateral has been removed.

All jurisdictions not having central registration now have provisions regulating the intra-provincial removal of goods subject to chattel mortgages. Jurisdictions following the uniform act provide that where 
chattels are permanently removed" from the district in which they were located at the time the bill of sale was executed, the bill of sale must be registered in the district into which the chattels have been removed within thirty days of the time the grantee receives "notice of the place" of removal, otherwise the bill of sale "ceases to be valid" as against creditors of the mortgagor, and subsequent purchasers and mortgagees taking in good faith, for valuable consideration and without notice. ${ }^{5}$ Ontario requires registration in the new county or district within two months of the removal without regard to the creditor's knowledge of the removal, otherwise the mortgage "is null and void as against subsequent purchasers and mortgagees in good faith for valuable consideration."

In the case of conditional sales, jurisdictions following the Uniform Act require registration in the new district within thirty days after the seller receives "notice of the place" to which the goods have been removed, otherwise the conditions sale "ceases to be valid" as against creditors, subsequent purchasers and mortgagees of the buyer "in good faith, for valuable consideration and without notice." statutory provisions regulating removals within the province; all other jurisdirtions have central registration.

It has generally been agreed that the time established for refiling in the new district following removal creates a period of temporary perfection and that third parties whose rights arise before expiration of that time are subordinate to the secured party even though the secured party does not file within the allotted time, or ever. ${ }^{8}$

Since the Ontario Personal Property Security Act establishes a local-central filing system, the intra-provincial removal problems obviously will not arise thereunder. In theory therefore the Act's localcentral registration system represents unquestionable improvement over any of the alternatives of Article $9 .^{\circ}$

\section{II.-INTERPROVINCIAL REMOVALS}

Pre-Act Choice of Law Rules-The Nature of the Problem:

Choosing the applicable law to resolve conflicting claims in collateral moved from one province or state into another has been a vexing conflicts problem for all of North America, but much less confusion has reigned in Canada on this point than in the United States, partly because of Canada's smaller number of jurisdictions and partly because Canadian judges have been less disposed to invent new approaches to the problem. Speaking of the diverse theories applied in the United States prior to the Uniform Commercial Code, Professor Gilmore states that " $[t]$ here is no consensus, not even the half-success of a split between 'majority' and 'minority' rule; there are merely hundreds, if

1 McIntyre v. Prefontaine (1915) 8 W.W.R. 1149, 25 Man. R. 572, 23 D.L.R. 139 (C.A.); Hodgins v. Johnston (1880) 5 O.A.R. 449 (C.A.); Clarke v. Bates (1871) 21 U.C.C.P. 348 (C.A.).

5 Model Bills of Sale Act, s. 12

6 R.S.O. 1960, c. 34, s. 22 .

7 Model Conditional Sales Act, s. 4 (5)

8 McIntyre v. Prefontaine (1915) 8 W.W.R. 1149, 25 Man. R. 572, 23 D.L.R. 139 (C.A.) Jones v. Twohey (1908) 8 W.L.R. 295, 1 Aita. L.R. 267; Wallace v. Scott (1907) 5 W.L.R. 341; 16 Man. R. 594 (C.A.); see also Barbour v. Moore (1921) 3 W.W.R. 576, 14 Sask L.R. 548, 62 D.L.R. 129 (C.A.)

o For a discussion of local, central and local-central registration in Canada, see Lee, supra, $n .3$ at 471-77. For a discussion of the intra-state filing provisions of Article 9. see Glimore, Security Interests in Personal Property, 597-99 (1965). 
not thousands, of cases, riding off, like the classical horseman, in every direction." 10 Some of the cases adopt the mobilia sequuntur personam theory, some the "first situs" rule, others the lex situs at the time the action commences, some the vague ground of "comity;" still others defy classification. ${ }^{11}$ The difficulty faced by a Canadian judge or anyone else who attempts to discover the "true choice of law rule" by resorting to American cases for guidance, as sometimes done in the past, is obvious; he can find support for virtually any notion he may wish to follow. ${ }^{12}$ For example, in view of the fact that an out-of-province secured party quite consistently prevailed over subsequent third parties in the absence of a special statutory conflicts provision, as in many American cases, we might easily conclude that it was the law of the situs from which the collateral came and in which the original transaction occurred that was being applied with respect to matters of priority, again, as in many American cases. ${ }^{13}$ But the language of the Canadian cases makes it fairly clear that it was the law of the ultimate situs that was being applied in the original instance and that the outof-province secured party won not so much because of his compliance with the chattel security law of the transaction situs (first situs), but because the statutory law of the ultimate situs simply did not deal with the problem and thus the nemo dat rule would preserve the secured party's common law proprietary interests. The confusion can only be compounded by an attempt to apply an American case dealing with a conflicts statute to a question arising in a Canadian jurisdiction having a similar provision, particularly where the American courts place significance on whether the secured party had knowledge of or had consented to the removal. ${ }^{14}$

The usual pattern has been that $A$ sells goods to $B$ by conditional sale in province $X$, where the goods are located, with title reserved in $A$ until payment of the balance of the price; or $B$ owning chattels in $X$, conveys title to $A$ by way of mortgage as security for a debt. $B$ then removes the property to $Y$, a foreign jurisdiction, usually without the knowledge or consent of $A$, and there the property is sold, mortgaged, levied upon by a creditor, or taken over by a trustee in bankruptcy. Where should the agreement have been registered to protect the secured party in these circumstances? Implicit in this issue is the more narrow question, which law applies, the law of $X$, the situs of the goods at the time of the original transaction, or the law of $Y$, the situs of the subsequent transaction and the jurisdiction in which the dispute has arisen, or perhaps some other law. Almost invariably Canadian courts have

10 See G. Gllmore, supra, n. 9, 599-616.

11 Id.

12 But this is not to suggest that an examination of the American cases is without merit. See MacIntyre, The Use of American Cases in Canadian Courts, (1966) 2 U.B.C. L. Rev. 478.

13 Vernon, Recorded Chattel Security Interests in the Conflict of Laws, (1962) 48 Iowa L. Rev. 346, at 350,355 .

14 Gilmore, supra, $n .9$ at 605 . In selecting the choice of law, Canadian cases have not drawn distinctions on the presence or absence of knowledge of or consent to removal. Traders Finance Corp. v. Dawson Implements Ltd. (1958) 26 W.W.R. 561 removal. Traders Finance Corp. v. Dawson Implements Ltd. (B.C.). Dicey. Conflict of Laws (7th ed.) 545. A dictum in Singer Sewing at 563 (B.C.). Dicey, Conflict of Laws (7th ed.) 545. A dictum in Singer Sewing Machine Co. v. McLeod (1888) 20 N.S.R. 341 (C.A.), which implies otherwise has not been followed. See note, Condiditional Sales and the Conflict of Laws, (1960) 1 the debtor, in province $Y$, a foreign jurisdiction, is no less misleading where $A$, the secured party, has not given consent to removal than where he has. The equities welgh more heavily of course in favor of $A$ where he has no knowledge of the removal than when he has, and this is no doubt the basis for the American distinction. 
held that the law of the situs to which the goods have been removed, in this case $Y$, is to be applied in determining proprietary interests, and this is true not only where $Y$ does not have a specific statutory conflicts provision of the nature to be discussed later, but also where it has. ${ }^{15}$ This is not to suggest, however, that the outcome is the same under statutory provisions as at common law. Only personal rights under the contract, such as rights inter partes, and construction of the contract, are to be determined by the proper law of the contract. ${ }^{16}$ The courts have not always been particularly articulate in indicating that they have followed the lex situs of the subsequent transaction in reaching their decision, but there is usually sufficient evidence in the opinions to indicate this is in fact what has been done (assuming the court has directed its mind to the classification problem at all, and it is not always clear that it has).$^{17}$ It is also true, however, that the result is often consistent with the conclusion that would have been reached if the lex domicilii, "first situs," or "comity" theories had been applied, as they frequently have been in American cases. The choice of law has not been influenced by whether the chattel security device involved is a chattel mortgage, conditional sales agreement, or lien note of the type common in Manitoba and other western provinces.

\section{Pre-Act Choice of Law in Absence of Statutory Provisions:}

Where a special conflicts provisions is not found in the relevant chattel security statute of the situs, $Y, A$, the conditional vendor or chattel mortgagee, is not required to comply with the registration or other perfecting requirements of the domestic statute in order to preserve his rights. The ground usually given for this view is that the legislature presumably had not intended the statute to apply to security interests acquired in a foreign jurisdiction. A reading of the statute could lead to no other logical conclusion since practically all statutes, prior to the rise of central registration, contained a requirement that a chattel mortgage or conditional sale must be registered either in the district where the goods are located, or where the secured party resides, within a certain number of days after execution of the agreement; otherwise the device will be null and void as against creditors, subsequent purchasers, and mortgagees. Obviously parties executing a chattel mortgage or conditional sale in jurisdiction $X$, where the goods

15 Traders Finance Corp. v. Dawson Implements Ltd. (1958) 26 W.W.R. 561 (B.C.) (conditional sale): McAloney v. Mclnnis (1955) 37 M.P.R. 131, 2 D.L.R. (2d) 666 (N.S.): Colonial Finance Corp. v. Eltis (1949) 2 W.W.R. 799 (Alta); Re Satisfaction Stores (1929) 11 C.B.R. 141, 60 N.S.R. 357, [1929] 2 D.L.R. 435 (C.A.); Re Hudson Fashion Shoppe Ltd. (1926) 7 C.B.R. 68, 58 O.L.R. 130, [1926] 1 D.L.R. 199; SawyerMassey Co. v. Boyce (1908) 8 W.L.R. 834, 1 Sask L.R. 230 (C.A.); Johnes v. Twohey (1908) 8 W.L.R. 295, 1 Alta. L.R. 267 (chattel mortgage); National Cash Register Co. v. Lovett (1906) 39 N.S.R. 540 (C.A.) (conditional sale); Gosline v. Dunbar (1894) 32 N.B.R. 325 (C.A.) (chattel mortgage); Singer Sewing Machine Co. v. McLeod (1888) 20 N.S.R. 341 (C.A.) (chattel mortgage); River Stone Co. v. Sill (1886) $120 . R$. 557 (C.A.) (chattel mortgage). And see Comment, 32 Can. Bar Rev. 900 at 904 (1954) wherein it is stated that the British Columbia conflicts legislation "predicates the lex situs." See also Ziegel, Conditional Sales and the Conflict of Laws, (1967) 45 Can. B. Rev. 284 at 290-291, 296, 312-313. Contra: Hannah v. Pearlman [1954] 1 D.L.R. 282 at 284. (B.C.) (the lex loci contractus is to be applied). For a debate of the appropriate principle see Comments, (1954) 32 Can. Bar Rev, 900; 1174; 1181. For an American case, similar in princlple, upon which ignominy has been heaped, see Re Steen 257 F. $2 d 297$ (7th Clr. 1958), commented upon in G. Gilmore, supra, n. 9 at $612-13$.

16 Sawyer-Massey Co. v. Boyce (1908) 8 W.L.R. 834 at 838, 1 Sask. L.R. 230 at 235-36; Jones v. Towhey (1908) 8 W.L.R. 295 at 299, 1 Alta. L.R. 267 at 272-73. Ziegel, supra, n. 15,313 et. seq.

17 See, e.g. Cline v. Russell (1909) 10 W.L.R. 662, 2 Alta. L. R. 79; Jones v. Twohey (1908) 8 W.L.R. 295, 1 Alta. L.R. 267; Sawyer-Massey Co. v. Boyce (1908) 8 W.L.R. 834, 1 Sask. L.R. 230 (C.A.): Gosline v. Dunbar (1894) 32 N.B.R. 325 (C.A.); Singer Sewing Machine Co. v. McLeod (1888) 20 N.S.R. 341 (C.A.). 
are located, could not be expected to comply with a registration requirement in $Y,{ }^{18}$ especially where the removal to a foreign jurisdiction was not contemplated, as it would not be in the case of unauthorized removals. Thus, in the absence of any other applicable domestic statute or, it would seem, circumstances such as those in Pickering v. Busk, ${ }^{19}$ the common law nemo dat quod non habet principle will be applied. This rationale, however, raises the questions whether $B$, the chattel mortgagor or conditional vendee in jurisdiction $X$, has any interest in the collateral to transfer to an innocent third party in $Y$ following a removal, and which law governs the determination. Quite consistently the question has been answered by resorting to the law of the situs where $B$ obtained his alleged interest or power, i.e., the law of the jurisdiction in which the transaction was consummated and in which the collateral was originally located. ${ }^{20}$ If $A$ has complied with the requirements necessary to perfect (or "validate," as the term is sometimes used under pre-Act law) his interest under the law of $X$, there is little problem, because $B$ clearly has nothing to transfer to $C$ in $Y$, at least nothing which would take priority over A's claim. ${ }^{21}$

Suppose, however, that $A$ has not done all that he should to perfect his security interest under the laws of $X$. Is $A$ 's interest vulnerable to attack by third parties in $Y$ ? Whether third parties of the type protected by the law of $X$ if they had intervened in $X$ while the collateral was still there may prevail in $Y$ depends on whether the statute of $X$ is to be given extraterritorial effect. The vast majority of cases have either expressly or impliedly answered the question in the negative.22 All that need be shown then is that $A$ in fact has some interest in the collateral under the law of $X$ and this interest will be protected in $Y$, again provided a statute has not displaced the application of the nemo dat rule. Thus, in the absence of a statutory choice of law rule the out-of-province secured party almost uniformly was given priority over subsequent third parties who, it will be noted, were unable to protect themselves.

\section{Pre-Act Statutory Choice of Law Provisions:}

Under the common law conflicts rule it is quite obvious that in removal cases third parties are subject to the same type of risks they faced in purely domestic transactions prior to the general adoption of statutes requiring registration of chattel mortgages and conditional sales agreements, i.e., the possibility of a secret lien held by an out-of-province secured party, since the common-law rule requires nothing to be placed

18 McAloney v. McInnis (1965) 37 M.P.R. 131 at 134, 2 D.L.R. (2d) 666 at 670 (N.S.); Cline v. Russell (1909) 10 W.L.R. 666, 2 Alta. L.R. 79; Sawyer-Massey Co. v. Boyce (1908) 8 W.L.R. 834 at 839, 1 Sask. L.R. 230 at 237 (C.A.). McGregor v. Kerr (1896) 29 N.S.R. 45 (C.A.); Bonin v. Robertson (1893) 2 Terr. L.R. 21 (C.A.); Singer Sewing Machine Co. v. McLeod (1888) 20 N.S.R. 341 (C.A.).

10 (1812) 15 East. 38, 104 E.R. 758.

10 Cline v. Russell (1909) 10 W.L.R. 666, 2 Alta. L.R. 79; Sawyer-Massey Co. v. Boyce (1908) v 8 W.L.R. 834, 1 Sask. L.R. 230 (C.A.); Bonin v. Robertson (1893) 2 Terr. T.R. 21 at 28,29 (C.A.); Singer Sewing Machine Co. v. McLeod (1888) 20 N.S.R. 341 (C.A.): Ziegel, sumra, n. 15 at 285-287.

21 Jones $v_{.}$Twohey (1908) 8 W.L.R. 295, 1 Alta. L.R. 267; Sawyer-Massey Co. v. Boyce (1908) 8 W.L.R. 834, 1 Sask. L.R. 230 (C.A.); National Cash Register Co. v. Lovett (1906) 39 i..S.R. 540 (C.A.); Bonin v. Robertson (1893) 2 Terr. L.R. 21 (C.A.); Singer Sewing Machine Co.v. MCLeod (1888) 20 N.S.R. 341 (C.A.).

22 McAloney v. McInnis (1955) 37 M.P.R. 131, 2 D.L.R. (2d) 666 (N.S.): Cline v. Russell (1909) 10 W.L.R. 666, 2 Alta. L.R. 79; Jones v. Twohey (1908) 8 W.L.R. 295, 1 Alta. L.R. 267. Contra, Hannah v. Pearlman [1945] 1 D.L.R. 282 (B.C.). See discussion of point in Comment. (1954) 32 Can. Bar. Rev. 900 (note difference of opinion at 908); Comment, (1954) 32 Can. Bar. Rev. 1174 and 1181 . 
on record in $Y$ to rebut the apparent ownership of the party in possession. Moreover the common law doctrine of Twynes Case which would invalidate an unregistered chattel mortgage as against certain third parties appears to have been ignored by Canadian courts in this type of case. ${ }^{23}$ To rectify the inequities that prevailed under these circumstances, special conflicts provisions, somewhat similar to section 14 of the American Uniform Conditional Sales Act, ${ }^{24}$ have been adopted by most jurisdictions for chattel mortgage and conditional sales statutes. ${ }^{25}$

All jurisdictions except Ontario have provisions in their chattel mortgage statutes regulating the rights of third parties in the event of permanent interprovincial removals. The Uniform Act states that unless the grantee registers in the new province within thirty days of receiving notice of "the place" of removal, the grantee may not "set up any right of property or right of possession in or to the chattels" as against creditors, subsequent purchasers, or mortgagees of the grantee taking in "good faith for valuable consideration without notice." "British Columbia requires registration within twenty-one days of the "date ... the grantee learns" of removal into the province; otherwise the mortgage is "null and void with regard to the property in or right to possession" of the chattels as against a liquidator, assignee, receiver, trustee, levying sheriff, and a subsequent bona fide purchaser or mortgagee for valuable consideration. ${ }^{27}$

With respect to conditional sales the Uniform Act provides that unless registration is effected in the province of the new situs within thirty days after the seller receives "notice of the place" to which the goods have been removed, the seller may not "set up any right of property in or right of possession" to the goods as against creditors and subsequent purchasers of the buyer "in good faith for valuable consideration without notice." Subsequent mortgagees are not protected. ${ }^{28}$ A similar provision regulates the rights of conditional sellers claiming a right of revendication, preference, or dissolution of the sale arising under Quebec law. ${ }^{29}$ In British Columbia reservation of property in the seller of goods is "null and void" as against a trustee in bankruptcy, receiver, liquidator, levying sheriff, or subsequent bona fide purchaser or mortgagee for valuable consideration, "unless the requirements of the Act are complied with;" one of the Act's requirements is, of course, registration within twenty-one days of the date the "seller learns" that "any of the goods ... have been removed." 30 Ontario regulates a seller's right of "revendication or [right] to resume possession of the goods . . . upon default in payment" in which case registration must be "within twenty days after the date on which the goods are

23 Tyne's Case (1601) 3 Co. Rep. 806, 76 E.R. 809. Third partles may not be misled so easily in the case of motor vehicles carrying-out-of-province license plates and perhaps such evidence ought to be held a basis for putting third parties on inquiry, perhaps such evidence ought to be held a basis for putting third parties on inguiry, but this has not yet happened. See Cormier v. Coster (1914) 19 D.L.R. 701 (N.S.):

24 For comment on s. 14 of the American Uniform Conditional Sales Act see Vernon. supra, n. 13, at $369-72$.

25 Ostler v. Industrial Acceptance Corp. (1963) 45 W.W.R. 673 at 678, 42 D.L.R. (2d) 750 at $754-55$ (B.C.); Traders Finance Corp. v. Dawson Implements Ltd. (1958) 26 W.W.R. 561 at 563 (B.C.) Comment, (1954) 32 Can. Bar Rev. 900 at 905-06.

26 The Model Bills of Sale Act, s. 13.

271961 S.B.C., c. 6, ss. 10 (1) (c) and 16.

28 The Model Conditional Sales Act, s. 7.

39 Id., s. 8. v. Industrial Acceptance Corp. (1963) 45 W.W.R. 673, 42 D.L.R. (2d) 750 . 
brought into Ontario," otherwise the seller is subject to the usual penalties for nonregistration. ${ }^{31}$ Saskatchewan allows thirty days from the same date, i.e., the date of arrival of the goods into the province for registration. ${ }^{32}$

As indicated earlier, the existence of a statutory conflicts provision of this nature does not alter the choice of law rule formerly in force in virtually all jurisdictions, the lex situs, ${ }^{33}$ but merely establishes the conditions under which $A$ 's interest in the collateral, whatever it might be as determined by the law of $X$, will be recognized in $Y$. Speaking of the purpose of conditional sales acts generally, Wilson $J$. has said that it is "to protect innocent purchasers for value against the common law rights of the unpaid vendor. The Conditional Sales Act, in effect, alters the common law by requiring that a vendor, if he is to retain his common law rights, register his agreement. Registration confers no rights on the vendor that he did not have by common law; failure to register deprives him of his rights under common law."34 By virtue of the implementation of statutory conflicts provisions this comment becomes as pertinent to the rights of secured parties (including chattel mortgagees as well as conditional vendors) whose property has been removed to another province as it is to purely domestic transactions. It is therefore important to consider the effect of the statutory provisions in the light of various fact patterns to determine the circumstances under which $A$ 's common law rights will be preserved.

Starting with the simplest hypothetical, suppose $A$ 's security interest has been perfected in $X$ and after removal ${ }^{35}$ is registered in $Y$ within the statutory time ${ }^{36}$ and before any third party has intervened. There has been no reported case on these facts, and probably no third party would have the temerity to bring action under such adverse conditions. If the statute is intended to protect $A$ under any circumstances, he would be protected here. ${ }^{37}$ Even if $A$ has not perfected his interest in $X$, it has been held he will nevertheless be protected by compliance with the statutory requirements of $Y .^{38}$

An equally clear case is that involving the rights of a third party that arise after expiration of the prescribed time for $A$ 's registration in $Y$, and before registration takes place. Consistently and reasonably the cases have allowed the intervening third parties to prevail. ${ }^{39}$

A more difficult question is whether the rights of a third party that arise either before the statutory period begins to run or after it begins

311960 R.S.O., c. 61, s. 12.

321965 R.S.S., c. 393, s. 8.

a3 See cases collected, supra, n. 15

84 Hannah v. Pearlman [1954] 1 D.L.R. 282, at 286 (B.C.).

35 As to what constitutes "permanent removal" see General Motors Acceptance Corp. v. Prophet (1959) 29 W.W.R. 44 at 46 (Alta.); cf. Hodgins v. Johnston (1880) 5 O.A.R. 449 (C.A.), and Clarke v. Bates (1871) 21 U.C.C.P. 348 (C.A.) regarding

86 General Motors Acceptance Corp. v. Prophet (1959) 29 W.W.R. 44 at $46-47$ (Alta.), General Motors Acceptance Corp. v. Prophet
contains the suggestion that something less than knowledge may consitute notice.

The impact of the Sale of Goods and Factors Act must be considered, however. This Tubject is discussed below.

$38 \mathrm{Re}$ Union Acceptance Corp. and Indian Cycle \& Sports Ltd. (1955) 16 W.W.R. 283 at 286; [1955] 4 D.L.R. 822, at 825 (Alta. A.D.): McAloney v. McInnis (1956) 37 M.P.R. 131 at 133, 2 D.L.R. (2d) 666 at 668 (N.S.); and see Traders Finance Corp. v. Dawson Implements Ltd. (1958) 26 W.W.R. 561 at 565 (B.C.)

39 General Motors Acceptance Corp. v. Prophet (1959) 29 W.W.R. 44 (Alta.): Traders Finance Corp v. Enerson (1942) 3 W.W.R. 673 [1943] 1 D.L.R. 214 (Sask.): Re Farley and Grant; ex parte Cummins (1936) 17 C.B.R. 87, [1936] I D.L.R. 57 (Ont.); Re Modern Cloak Co. (1930) 11 C.B.R. 442, 38 O.W.N. 427: Re Satisfaction Stores Re Modern Cloak Co. (1930) 11 C.B.R. 442, 38 O.W.N. 427: R.
(1929) 11 C.B.R. 141, 60 N.S.R. 357, [1929] 2 D.L.R. 435 (C.A.). 
to run but before it expires, may prevail over $A$ if $A$ has effected a timely registration. The answer depends of course on whether the time prescribed is a "temporary perfection period," that is, whether the operation of the rest of the section is in effect suspended for the statutory period, during which the common law prevails. Otherwise stated the question is how far did the legislature intend to alter the common law. Alberta takes the position that $A$ 's security interest is temporarily perfected in $Y$ until the time has expired. ${ }^{40}$ Under this view $A$ would prevail over an intervening third party even though $A$ never registers, so long as the third party's rights arise during the statutory time. ${ }^{41} \mathrm{~A}$ recent British Columbia case has construed a similar provision to mean that $A$ 's common law rights may be superseded from the moment possession of the collateral is delivered to $B$, unless registration is effected in $Y$ prior to the intervention of any third party of the type protected by the Conditional Sales Act. ${ }^{ \pm 2}$ But an even more recent case has implied otherwise, i.e., that the time prescribed for registration in $Y$ constitutes a temporary perfection period, and this implication, it is submitted, represents the correct view..$^{43}$

In addition to the chattel mortgage and conditional sale conflict provisions most jurisdictions also have provisions patterned after section 25 of the English Sale of Goods Act and/or section 9 of the English Factors Act which might affect the rights of $A .{ }^{44}$ However, Alberta and Manitoba have excluded conditional sales from the operation of their Sale of Goods Act."5 In jurisdictions not having an exclusionary provision the question arises whether provisions of the Sale of Goods Act or Factors Act can limit the rights of $A$. More to the point of this article the question is raised whether such provisions of the law of $Y$ are to apply to property rights reserved or received by virtue of a secured transaction in $X$, a foreign jurisdiction. There would seem to be little evidence that the legislatures intended to exclude application of such legislation to $A$ 's interest in $Y$, although it has been argued with respect to the British Columbia Act that "when section 32 speaks of a

10 Colonial Finance Corp. v. Ellis (1949) 2 W.W.R. 799 (Alta.) (bona fide purchaser prior to expiration of time for $A$ 's registration is not a "subsequent purnhaser). A more recent case held that "the common law right of a mortgagee is preserved [in this case also as against a "subsequent puchaser"] until the expiration of the time limited for filing." Rennie's Car Sales v. Union Acceptance Corp. (1955) time limited for filing." Rennie's Car Sales V. Union Acceptance Corp. (1955) to come to this conclusion notwithstanding section 2 (1) which defines "subsequent purchasers" as person "to whom chattels are conveyed or mortgaged "., ". (ii) after the making of the mortgage mentioned in section 13 contains the uniform conflicts provision. For a contrary view see Bowker, Panel On Bills of Sale, Chattel Mortgages and Conditional Sales Agreements (1955-61), 1 Aita. L. Rev. 273 at 291 . The Rennie's case is significant because it involves the Uniform Act and presumably would be persuasive in other jurisdictions which have it.

41 See Peterson v. Hulbert (1905) 36 S.C.R. 324 (Alta.).

42 Ostler v. Industrial Acceptance Corp. (1963) 45 W.W.R. 673 at 678, 42 D.L.R. (2d) 750 at 754 (B.C.). The phrase "subsequent purchaser" came up for construction and this in turn raised the question, subsequent to what? The court held that the term referred to a purchaser taking after the conditional vendee's receipt of possession of the goods rather than after the expiration of the twenty-one days allowed for registration of forelgn conditional sales agreements. This decision hardly seems sound in view of the elementary principle that a statute purporting to derogate from the common law is to be construed strictly. An examination of the counterpart section of British Columbla's chattel mortgage act, 1861 S.B.C. . c. 6, ss. 10 and 16, would appear to raise an irrefutable implication that registration within the allotted time will preserve $A^{\prime} s$ common law rights, although there is no
rational justification for making a distinction between the two devices under rational justification
such circumstances.

43 Steiner v. Laurentide Corporaiton Ltd. (1967) 59 W.W.R. 435 at 437 and 439 . No reference was made to Ostler v. Industrial Acceptance Corp. (1963) 45 W.W.R. 673/42 D.L.R. (2d) 750, at 754-55 (B.C.)

44 National Cash Register Co. v. Lovett (1906) 39 N.S.R. 540 at 547 (C.A.); Falconbridge, Conflict of Laws 480 (2d ed. 1954).

451955 R.S.A., c. 295 , S. 27 (3); 1954 R.S.M., c. 233 , s. 27 (3); 1951 R.S.P.E.I., c. 55, s. 10 (2). 
'buyer' or 'seller' it refers to a sale taking place within the province." 40 But the acts contain no provisions which make them logically inapplicable to $A$ 's rights, as was the case with the chattel mortgage and conditional sales acts, and we have seen that it was on this basis they were said to be inapplicable to foreign property rights, prior to the wide adoption of special conflicts provisions. However, an argument can be made that application of the Sale of Goods Acts and Factors Acts are impliedly excluded from effecting $A$ 's rights, ${ }^{17}$ and this would seem to be reasonable, particularly if $A$ has satisfied the requirements of Y's conditional sales act. ${ }^{18}$

\section{Choice of Law Under the Ontario Personal Property Security Act:}

The simplest choice of law question arises when the collateral and all transactions related to it are located in a single jurisdiction and the litigation arises therein. In this instance there is no removal problem at all and thus no conflict of laws question, but the rationale of the general common law rule which looks to the lex rei sitae is applicable. Turning to the Ontario Personal Property Security Act we find the general rule stated in Section 2 as follows: "this Act applies . . . to every transaction ... that in substance creates a security interest." Implicit in this declaration is the proposition that the Act applies only to transactions involving personal property and fixtures located within the jurisdiction since the Act obviously may not govern extraterritorial secured transactions, and presumably it is the location of the collateral at the time of attachment that is material. Thus if the secured transaction occurs in Ontario and the collateral is located in Ontario the Act applies, and presumably any agreement between the debtor and secured party which purports to exclude application of the Act in any way that would affect the rights of third parties, and even the rights of the parties themselves where this is prohibited, would be invalid regardless of other "connecting factors." ${ }^{0}$ If, however, the collateral is located in province $Y$ and litigation arises in Ontario, the Ontario courts, under the common law rule, would apply the law of the foreign jurisdiction. ${ }^{50}$ Similarly, courts sitting in province $Y$ dealing with a dispute over collateral located in Ontario would apply the law of Ontario, which of course includes the Act. But the Act contains special choice of law provisions which supersede the general rule of section 2 when removal problems are involved.

As the discussion of the relevant pre-Act law has illustrated, the problems become more complex when the collateral is removed from one jurisdiction to another following the secured transaction, or where the parties create and perfect the security interest in one jurisdiction and the collateral is in another. In addition special problems arise when the collateral consists of intangibles. To accommodate diverse problems of this nature the Act contains rules of two types: those keyed to

40 Cnmment, 32 Can. Bar Rev. 1181 at 1187 (1954)

47 Comment, (1954) 32 Can. Bar Rev. 1181, 1187; contra, Comment, (1954) 32 Can. Bar Rev. 1147 at 1180-81.

48 Joanes, supra, n. 3; Traders Finance Corp. v. Dawson Implements Ltd. (1958) 26 W.W.R. 561 at 565-66 (B.C.). In the Traders Finance Corp. case it was held that application of the Sale of Goods Act cut off $A$ 's interest as against a bona fide purchaser, but it is to be noted that $A$ had not complied with applicable registration purchaser, but it is to be noted that $A$ had not complied with applicable registration
requirements. See also Century Credit Corp. v. Richard (1962) 34 D.L.R. (2d) 291 at 296 (C.A.).

40 Compare Úniform Commercial Code (U.C.C.) s. 1-105

so Falconbridge, supra, n. 44 at $443-44$. 
certain classes of collateral (intangibles and certain mobile equipment) and the chief place of business of the debtor, sometimes described as the domiciliary rule, and those based on the more traditional situs theory. The dichotomy is established by section 5 which provides that with respect to the validity and perfection of a security interest in "intangibles or ... goods of a type that are normally used in more than one jurisdiction, if such goods are classified as equipment or classified as inventory by reason of their being leased by the debtor to others," the law of the jurisdiction in which the debtor's "chief place of business" is located controls. With respect to choice of law questions pertaining to the validity and perfection of security interests in all other types of collateral, the Act's situs rules apply. Since Ontario has no legislation comparable to the certificate of title acts of the United States, ${ }^{51}$ a provision corresponding to section 9-103(4) of Article 9 is not found in the Ontario Personal Property Security Act, and consequently both the domiciliary and the situs rules assume much greater importance than do the counterpart rules of Article 9.

\section{The Situs Rules: Sections 6, 7, \& 8:}

Eliminating from consideration the collateral that is subject to section 5 (intangibles and certain mobile equipment), we see that the situs rules contained in sections $6,7, \& 8$ govern all choice of law problems involving normally stationary equipment which crosses jurisdictional boundaries, pledgable intangibles such as instruments, chattel paper, documents of title, and securities, and perhaps most importantly, consumer goods, which includes the family automobile and other noncommercial motor vehicles as well as other personal and household goods.

In stating the applicable choice of law rules under conditions of removal, the provisions differentiate between "validity" and "perfection." Although "validity" is not defined by the Act it clearly relates to the formal requisites necessary for the creation of a security interest, and perhaps to the rights of the parties as between themselves." "Perfection" refers to the rights of the secured party as against third parties claiming a conflicting interest in the same collateral and arguably, in this context, to all other matters related to secured transactions including priorities, rights after default, etc. ${ }^{.3}$

The choice of law rule governing questions of "validity" of a security interest that has attached to collateral later moved into Ontario is contained in section 6 which provides:

(1) Where personal property, other than that governed by subsection 1 or 2 of section 5, was already subject to a security interest when it was brought into

01 Section 9-103 (4) contains a domicillary-type choice of law provision for resolving whether certificate of title legislation is the best means of achleving its avowed whether certificate of title legislation is the best means of achieving its avowed
purpose-the elimination of fradulent transfers following car thefts, unauthorized removals, etc.-in a country with only a few jurisdictions and where central registration is being adopted rather quickly. A national registration system would seem to be a superior approach. For a commentary on certificate of title laws see $G$. Gllmore, supra, n. 9, 623; Ziegel, The Legal Problems of Wholesale Financing of Durable Goods in Canada; (1963) 41 Can. Bar Rev. 54 at 117; Comment Security Interests in Motor Vehicles Under the U.C.S.: A New Chassis for Certificate of Title Legislation, (1961) 70 Yale L.J. 995.

52 As to the latter point it will be recalled that at common law the lexi loci contractus governs rights in personam. See supra, n. 13.

52 With respect to the domfelliary rule see $n$. 69 below and accompanying text. 
Ontario, the validity of the security interest in Ontario is to be determined by the law, including the conflict of laws rules, of the jurisdiction where the property was when the security interest attached. ${ }^{34}$

The primary rule governing "perfection" is contained in section 7:

(1) Subject to section 5 , a security interest in collateral already perfected under the law of the jurisdiction in which the collateral was when the security interest attached and before being brought into Ontario continues perfected in Ontario for sixty days and also thereafter if within the sixty-day period it is perfected in Ontario.

The sixty-day continuous perfection period will be shortened to fifteen days by notice to the secured party, as indicated by section 7 which goes on to provide:

(2) Nothwithstanding subsection 1, where the secured party receives notice within the sixty-day period mentioned therein that the collateral has been brought into Ontario, his security interest in the collateral ceases to be perfected in Ontario unless he registers the security agreement covering the collateral within fifteen days from the date that he receives such notice or upon the expiration of the sixty-day period, whichever is earlier.

Section 6 contains, in effect, an exception to the sixty-day perfection rule in the case of removals from jurisdictions which allow sellers the right to revendication:

(2) Where goods brought into Ontario are subject to the seller's right to revendicate or to resume possession of the goods, unless the seller registers a caution in the prescribed form within twenty days after the day on which the goods were brought into Ontario, such right is unenforceable in Ontario thereafter.

Sections $7(3)$ and 8 provide that where a security interest in collateral that has been removed into Ontario is unperfected, either because the sixty days has expired without perfection or because the security interest was not perfected in the jurisdiction of attachment, the security interest may be perfected in Ontario, but in both cases perfection dates from the time of perfection in Ontario.

The manner of satisfying the basic perfection rule is not stipulated in section $7(1)$, but section $47(3)$ indicates that registration of a "copy of the security agreement signed by the debtor or a caution in the prescribed form" are permissible modes. Since these sections do not appear to be exclusive on the point, taking possession of the collateral pursuant to the terms of the agreement is undoubtedly also an available alternative method of perfection. Possession as a mode of perfection may be particularly important to the secured party where removal without consent constitutes breach of the agreement, as it frequently does. Rather curiously, but specifically, section 7 (2) which is an innovation to Article 9, requires perfection by registration of "the security agrement ..." thereby appearing to supersede section $47(3)$. Thus neither registration of a copy of the agreement, or of a caution,

04 The Uniform Personal Property Security Act proposes an exemption to section 6 (1) as follows:

However, if the partles to the transaction understood at the time that the security interest attached that the property would be kept in Ontario and it was brought into Ontario within 30 days after the security interest attached for purposes other than transportation through Ontario, then the validity of for purposes other than transportation through Ontario, then the validity of This is a verbatim counterpart to the second sentence of section 9-103 (3) of Article 9. The amendment is reasonable since property intended by both parties for immediate removal to another jurisdiction obviously bears a high degree of relationship to the intended ultimate situs, always a relevant factor in selecting a choice of law rule, and the secured party's knowledge forewarns him of the need to of minimal formal requisites for the creation of a Ontario Act, a provision of this nature would make compliance by a foreign secured party a very simple matter. 
nor taking possession will satisfy the requirement of section $7(2)$ : the agreement itself must be registered. These divergent rules on the perfection requirements following removal present an obvious difficulty since the secured party in most instances will be induced to perfect in Ontario only because he has received notice that the collateral has been removed to that jurisdiction. If notice is received, however, the fifteenday rule comes into operation, thereby requiring registration of the security agreement itself. Of what value then is section $47(3)$ which appears to say, and does say, that either a copy of the agreement or a caution may be registered? The problem apparently arises from a superimposition of an innovation in the Act on rules that are otherwise basically consistent with the framework of Article 9, without sufficient thought being given to coordination of the two. It would seem desirable that section 47 (3) control the method of perfection for all transactions falling within section 7.

The idea of reducing the time to fifteen days following notice (a departure from Article 9), regardless of the original intention of the parties as to ultimate removal, is meritorious, but the implementation fails in part to achieve the desired results as will be illustrated later.

Comments made elsewhere regarding the perfection period for purely domestic transactions are also relevant to a consideration of the duration of validity of a reperfecting statement.ss

Section 7 "continues" the perfected status of a security interest perfected out of the province for sixty days following removal of the collateral into Ontario. Since the security interest "continues perfection in Ontario for sixty days," it is clear that this is a period of temporary perfection during which the secured party is entitled to all of the rights and privileges accorded a perfected security interest under the Act's scheme of priorities, whether or not the security interest is reperfected before the expiration of the sixty days. A bona fide purchaser within sixty days of a removal into Ontario, for example, would be subordinate to the secured party's rights if the security interest is valid under relevant law. Only lienors and purchasers whose rights arise after the expiration of the sixty days and before reperfection may defeat the secured party. Even if the security interest is not perfected within sixty days of removal, only parties who acquire rights that will defeat an unperfected security interest before reperfection pursuant to section 7 (3) may prevail.se Thus the Ostler case and other cases of a similar nature are repudiated by the Act; ${ }^{57}$ the principle of the Rennie's case is sustained..$^{88}$

Consistent with the Ontario and Saskatchewan Conditional Sales Acts, the sixty-day cut-off period of section $7(1)$ is applicable without regard to the secured party's knowledge of or consent to the removal. From

\footnotetext{
so See Lee, supra, n. 3 at 484-88.

38 See The Personal Property Security Act, s.0. 1967, c.73, s. 22. For an interesting disagreement between Professor Gilmore and the draftsmen of the comments to the U.C.C. (s. 9-103 (4) Comment 7 ) on whether third parties intervening prior to the expiration (s. 9-103 (4) Comment 7) on whether third parties intervening prior to the expiration
of the grace period may prevail over the secured party if he fails to perfect of the grace period may prevall over the secured party if he
before the grace period expires, see G. Gilmore, supra, n. 9, 667n7.

67 Ostler v. Industrial Acceptance Corp. (1963) 45 W.W.R. 673, 42 D.L.R. (2d) 750 (B.C.) ; see Industrial Acceptance Corp. v. Munro (1950) O.W.N. 220, [1950] 3 D.L.R. 80.

58 Rennie's Car Sales v. Union Acceptance Corp 16 W.W.R. 283, [1955] 4 D.L.R. 822 2 D.L.R. 215 (Alta.).
} 
the secured party's point of view a rule of this nature is of course more harsh than the rule of the uniform acts based on notice, but perhaps more fair when the position of innocent third parties is considered. Certainly the rule is not as harsh as the British Columbia rule established by the Ostler case which, in light of the available alternatives, appears to have been born of excessive sympathy for a bona fide purchaser, who purchased the automobile in question no later than thirty-seven days after removal into British Columbia. ${ }^{50}$ On the whole an arbitrary cut-off period appears to be more equitable as between two innocent parties than one based on notice since it tends to place the ultimate loss on the party most likely to be able to bear it and on the one who might be thought to have assumed some risk of loss under these circumstances by engaging in a nonpossessory secured transaction. By the same token a rule which requires notice as a condition to cutting off the out-of-province security interest, in effect, may protect the secured party for an infinite length of time under circumstances where third parties are unable as a practical matter to protect themselves. The reduction of the period from four months, as allowed by Article 9, to sixty days seems to be reasonable in view of the smaller number of jurisdictions involved.

Section 6(2) is patterned after a similar provision in the Uniform Conditional Sales $\mathrm{Act}^{\mathrm{ob}}$ and is essentially limited in application to removals from Quebec, since this is the only continental jurisdiction which provides for revendication. ${ }^{61}$ As indicated earlier the twenty-day cutoff period under this section is an exception to the sixty days applicable to removals from all other jurisdictions, but the twenty days is also a period of temporary perfection.

Section 7 (3) and 8 quite clearly establish reperfection or perfection, as the case may be, as of the time those events actually take place; that is, they do not have a relation-back effect. However, these sections raise a couple of questions of construction and policy. In section 7 (3) the period of perfection "takes effect" from the time of reperfection while under section 8 perfection "dates from the time of perfection." Is a difference in meaning intended? If not, why the variation in phraseology? If, as seems likely, no difference is intended, uniform phraseology should be used, particularly since "takes effect" has received judicial construction. ${ }^{\text {2 }}$ Article 9 uses "dates from the time of perfection" in both instances. The second problem arises in section 8 , which provides that following removal of collateral into Ontario an unperfected security interest "may be perfected in Ontario within thirty days from the date the collateral is brought into Ontario." Comparing the language of section 8 , "may be perfected . . . within thirty days" with that of section $47(5)$, "shall not be registered after thirty days" leads to the conclusion that the thirty-day provision in section 8 is not mandatory, in which case an application to the court for registration after thirty days pursuant to section 63 would not be required. But such a construction does not make much sense, since the thirty-day period, which is an

59 Ostler v. Industrial Acceptance Corp. (1963) 45 W.W.R. 673, 42 D.L.R. (2d) 750 (B.C.). 60 Model Conditional Sales Act, s. 8, and see Ontario Conditional Sales Act, R.S.O., 1960, c. 61, s. 12.

61 See the Quebec Civil Code arts. 1998, $1999,2246$.

62 Consolidated Finance Co. v. Alfke (1960) 31 W.W.R. 497 (Alta.). 
innovation to Article 9, apparently was intended to have some effect. But even assuming registration in Ontario within thirty days is construed to be mandatory, what reason could there be for imposing the requirement in section 8 and not inserting a similar requirement in section 7(3)? In both instances there is nothing on file for the benefit of third parties. It is submitted, however, that the problem is only of theoretical concern since the secured party will in reality be sufficiently motivated to perfect his security interest in Ontario, once he learns of the removal, because of the danger of being subordinated to the claims of third parties pursuant to section 22 , and that the thirty-day requirement of section 8 should be deleted.

Frequently parties enter transactions involving collateral that is intended, to the knowledge of both parties, for immediate removal to a province other than the one in which the property is located at the time of attachment. Suppose, for example, that $B$, a resident of Ontario, buys a car in province $Y$ for personal use or resale in Ontario, with the secured party taking a security interest in the automobile for the balance of the purchase price. Where and when must the secured party register to perfect his security interest? The answer must be found in either section 7 or section 8 . Assuming the secured party perfects in $Y$, section 7 becomes applicable and the security interest would appear to be deemed continuously perfected for sixty days under subsection (1). But subsection (2) limits the temporary perfection period to fifteen days where the secured party "receives notice within the sixty-day period . . . that the collateral has been brought into Ontario." Is subsection (2) applicable in this instance? Literally construed it is not, since notice was not received "within the sixty-day period" but rather knowledge of the intended removal was had before the sixty days began to run. Common sense would be affronted, however, if it were concluded that the subsection does not apply in this situation, thereby permitting the secured party sixty days to perfect in Ontario, since it would appear that it was for the very purpose of curtailing the life of a perfected "secret" security interest, where the knowledge of the secured party warrants it, that led to the incorporation of the fifteen-day qualification in the first place. Though the absurdity of any other conclusion is rather obvious, an amendment for the sake of clarification would seem to be desirable.

Actually a first-situs rule for perfection of a security interest in collateral intended by all parties for immediate removal to another jurisdiction makes little sense in any event, as suggested by the ultimatesitus rule adopted by the committee on the Uniform Act to govern matters of validity. ${ }^{63}$ However, the fifteen-day exception moderates the potential abuse of the sixty-day rule by the secured party provided the fifteen-day rule is applied to such cases, and it is submitted that it should be.

On the other hand the secured party may choose to perfect his security interest exclusively in Ontario, in which case perfection will date from the time of perfection pursuant to section 8. Of course the secured party runs the risk of subordination to third parties in province

68 Supra, n. 54. 
$Y$ if the collateral is not promptly taken to Ontario as planned. To protect himself against this eventuality the secured party would have to comply with Y's chattel security statutes, and in doing so he would bring his security interest under the operation of section 7 .

Thus the Act adopts the ultimate situs as the choice of law rule for perfection (section 8), except where the security interest is originally perfected in the first situs, in which case the first-situs rule applies (section 7), and the first-situs rule is adopted to govern matters of validity (section 6).

It would seem that in most cases where immediate removal is not contemplated by both parties, the secured party will have met both the validation and perfection requirements of the law of the situs of attachment, particularly where motor vehicles are involved. This was not true in Hannah v. Pearlman, ${ }^{64}$ however, and we might speculate on the manner in which that case would be disposed of under the Act. It will be recalled that in the Hannah case the conditional vendor failed to register in Manitoba but did register in British Columbia subsequent to the removal and the purchase, but within the statutory time limit under British Columbia law. The subsequent purchaser in British Columbia was permitted to prevail over the assignee of the conditional vendor by virtue of the application of Manitoba law by the British Columbia court. If the conclusion is accepted that since the conditional sales contract was not registered in Manitoba it would have been "invalid" under the provisions of the Act, as it was under pre-Act law as that term is generally used, then the decision would be upheld under the Act. However, if the distinction between validity and perfection is maintained, as it must be under the Act, the decision would be reversed, since although the conditional sales agreement was not registered according to the law of the first situs, it apparently satisfied the formal requisites for creation, and under the Act this is sufficient to validate the security interest.

\section{The Domiciliary Choice of Law Rule: Section 5:}

There is an area in the spectrum of chattel security choice of law problems covered by the common law and other pre-Act situs principles that does not conveniently lend itself to traditional modes of solution. The problems may be raised most pointedly by the question: With which law should a secured party comply to be assured of a valid and perfected security interest under all probable circumstances when the collateral consists of either intangibles or mobile equipment of the type that frequently crosses provincial boundaries in the normal course of business? Under the situs test this question becomes rather formidable. To minimize the difficulties inherent in the application of the situs rules, a criterion other than location is required. Accordingly the Act displaces the situs rules and establishes what might be described as a domiciliary rule with respect to security interests taken in intangibles and mobile equipment. As will be illustrated presently, in order to obtain maximum benefit from one aspect of the rule it is necessary that all jurisdictions with which the collateral might have contact 
have a similar law, and thus adoption of the rules by all other Canadian jurisdictions is highly desirable.

To appreciate the domiciliary rule as it applies to intangibles, it is necessary to keep in mind that at common law inter vivos transfers of interests in intangible as well as tangible property are governed by the lex rei sitae. $^{65}$ Nevertheless it is quite evident that intangibles of the type regulated by section 5-accounts receivable, contract rights, and all other rights not represented by a document embodying a right or claim which may be transferred by endorsement and delivery-have no real situs at all unless one is artificially assigned. Problems are compounded by the fact that the common-law rules used to determine the situs of various choses in action are uncertain or at best not uniform. For example, to use an illustration which will not be changed by the rules of the Act, the situs of a negotiable instrument is the place where the instrument is found, whereas the situs of a share is deemed to be located at the corporate registry. ${ }^{\circ 6}$ Under these circumstances, and even more so where "pure intangibles" are involved, the possibility for disagreement as to the place registration is to be effected and as to which law is to govern the rights of the parties, is unnecessarily magnified under pre-Act law. The Assignment of Book Debts Acts generally contain rules for registration somewhat similar to the approach taken by the Act, ${ }^{67}$ but there remains a large area of intangibles for which no provision is made.

With respect to the tangible collateral contemplated by section 5 , such as road building equipment, construction machinery, commercial harvesting equipment, rolling stock, airplanes, etc., ${ }^{68}$ the problems arise not from the difficulty of ascertaining a situs, but rather from the inherent mobility of the collateral and the practice of such collateral being moved over provincial borders in the normal course of business. In view of the common law, which determines proprietary interests by application of the law of the situs, and of the fact that nearly all jurisdictions now have a special conflicts provision which requires a refiling in the jurisdictions to which the collateral has been "permanently removed," the secured party who wants to be assured that his security interest will be protected against third parties must register in every jurisdiction into which the collateral might be moved, although the "permanently removed" qualification does moderate the burden of the secured party.

The Act rectifies these disparate problems by adopting a uniform choice of law which is both simple and reasonable. Section 5 provides:

(1) Where the chief place of business of a debtor is in Ontario, the validity and perfection of a security interest and the possibility and effect of proper registration with regard to intangibles or with regard to goods of a type that are normally used in more than one jurisdiction, if such goods are classified

65 Falconbridge, supra, n. 44.

66 Falconbridge, supra, $n$. 44 at $486,489,498$. The reason the domicillary rule will not affect this problem is that by definition it is not applicable to pledgable intangibles. But the lack of uniformity in the choice of law rules which determine the situs of 'pledgable intangibles' is of little concern with respect to validity and perfection in the field of chattel security law since a security interest taken in the vast majority of such collateral may be perfected only by taking possession. Thus even if section 5 were extended to include such collateral it would find little application in practice. As to Article 9, see Gllmore, supra, $\mathbf{n}$. 9 at 650-52.

67 See. e.g.. The Model Assignment of Book Debts Act, s. 5 (1).

68 Compare U.C.C. 8. 9-103 (2). 
as equipment or classified as inventory by reason of their being leased by the debtor to others, are governed by this Act.

(2) Where the chief place of business of a debtor is not in Ontario, the validity and perfection of a security interest and the possibility and effect of proper registration with regard to intangibles or with regard to goods of a type that are normally used in more than one jurisdiction, if such goods are classified as equipment or classified as inventory by reason of their being leased by the debtor to others, are governed by the law, including the conflict of laws, of the jurisdiction in which the chief place of business is located.

Thus it is the law of the jurisdiction in which the debtor has his "chief place of business" that determines the validity of a security interest and the place of registration, where appropriate collateral is involved. "Validity" is not defined by the Act, but it is a word broad enough to include virtually every aspect of a secured transaction except for perfection. "Perfection" would include the later reference in the section to registration which is an alternative method of perfecting a security interest under the Act. Although these particular elements are singled out for special mention, it does not appear that the particularization was intended to narrow application of section 5 to anything less than all aspects of a security interest regulated by the Act, including the default provisions, priority rules, etc., since any other conclusion would necessitate the application of one set of choice of law rules to one aspect of a problem and a different set to another. Certainly the more simple construction is desirable, but since reasonable minds might differ on this point perhaps an amendment for the sake of clarification would be in order. ${ }^{09}$

With respect to "tangibles" within the section, it is the type of collateral and not the use to which it is put that is important. Consumer goods such as the family car, for example, are clearly not within the section even though they normally cross provincial lines. On the other hand, even if collateral of the appropriate type is never taken over a provincial boundary, it is nevertheless the "chief place of business" and not the situs which determines the place of registration.

Various combinations of circumstances relevant to the domiciliary choice of law rules of the Act may arise. ${ }^{70}$ For example, the chief place of business of the debtor may be in Ontario and litigation may commence either within or without the province. If the litigation commences outside Ontario, the foreign province may or may not have a choice of law rule similar to the Act. Where litigation arises in a foreign jurisdiction governed by the common-law rule, the connecting factors may be either in the province of litigation, in Ontario, or in still another jurisdiction. Another set of problems may arise from location of the chief place of the debtor's business outside of Ontario. In this event the foreign jurisdiction may either not have the Act, with litigation arising in or out of Ontario, and with the common law connecting factors being located in Ontario or in still another province; or the foreign jurisdiction may have the Act, in which case the possibilities have already been adverted to. Obviously the situs of the property is irrelevant so long as Ontario's law is applicable, but this of course will

60 With respect to Article 9, Professor Gllmore approves the simpler construction. Gilmore, supra, n. 9, 320-21 n. 3. Contra, Cavers, The Conditional Seller's Remedies and the Choice-of-Law Process-Some Notes on Shanahan, (1960) 54 N.Y.U. L. Rev. 1127 at 1145 .

70 For a corresponding consideration of the place-of-records rules under Article 9 see Gllmore, supra, n. 9 at $220-23$. 
not always be the case, and for this reason, as earlier suggested, full advantage of the domiciliary rule cannot always be had unless provinces where the collateral would be deemed to be located under common-law principles also have a similar law. The various possibilities may be illustrated as follows.

Beginning with the simplest hypothetical, assume that the chief place of business of the debtor is in Ontario and that litigation regarding the collateral arises there. Section 5(1) stipulates that the Act will be applied to all matters relating to the "validity," "perfection," and "the possibility and effect of proper registration." Accordingly if the chief place of business is in Ontario and litigation arises there, the courts would be bound to apply Ontario law to all aspects of the secured transaction.

If the chief place of business is in Ontario and the litigation arises in province $Y$, the applicable law will depend on whether province $Y$ has legislation similar in effect to Ontario's Act. Suppose that it does have a similar law and that all relevant contacts other than the chief place of business are in province $Y$. Pursuant to province $Y$ 's counterpart to section $5(2)$, province $Y$ will forego the application of its own law governing the "validity and perfection" of the security interest in the intangibles or mobile equipment, and apply Ontario law, which of course includes the Act. Accordingly registration under Ontario's Act would perfect the interest, while registration in province $Y$ would not.

Suppose, however, that province $Y$ does not have a law corresponding to Ontario's Act but that the chief place of business is still in Ontario and all the other contacts are in province $Y$. If litigation arises in province $Y$, it will again turn to its conflict of laws rules, as in the previous example, but in this instance no section or law requires province $Y$ to relinquish application of its own laws. It will therefore determine the validity and perfection of the security interest by commonlaw principles which, as we have seen, hinge on the situs of the collateral, which may be found to be in province $Y$, or in Ontario, or in some other jurisdiction. But in this instance the situs is in province $Y$ since it was stated that all contacts, and therefore the situs, were located there. However, if litigation had arisen in Ontario, it is clear that the courts would have determined validity and perfection under the Act, thereby necessitating registration in Ontario to perfect his interest in Ontario and in province $Y$, at least, to be assured of adequate protection. Under these circumstances the advantage of all provinces having a choice of law rule similar to the Act is apparent. Taking the problem a step further, suppose the litigation had arisen in province $Z$ and assume again that the chief place of business is in Ontario and all other contacts are in province $Y$. The applicable law would depend on whether province $\mathrm{Z}$ has an act in force similar to Ontario's Act. If $\mathrm{Z}$ has the Act, Ontario's law will govern; if it does not, under common-law principles, Y's law, the lex rei sitae, will govern. ${ }^{71}$

71 First National Bank of Minneapolis v. Mann (1925) 2 W.W.R. 525, 19 Sask. L.R. 546, [1925] 3 D.L.R. 648 (C.A.); River stove Co. v. Sill (1886) 12 O.R. (C.A.). 
As indicated above, the Act also covers the problems which arise when the chief place of business is located outside of the province. Suppose province $Y$, for example, does not have the Act and that all other contracts are in Ontario, where the litigation arises, but that the debtor's chief place of business is in province $Y$. Under Section 5 (2) Ontario will be obliged to relinquish jurisdiction so to speak to province $Y$. Province $Y$ would not accept jurisdiction and apply its own law, however, since all the contacts are in Ontario and the validity and perfection of a security interest would not depend upon location of the debtor's chief place of business under the common-law conflicts rules of province $Y$. Fortunately section $5(2)$ states that the foreign law includes its "conflicts of laws rules." Since those rules would cause province $Y$ to decline jurisdiction on the ground that common law attaches no significance to a debtor's chief place of business, jurisdiction would be returned to the Ontario courts which would pick it up and apply Ontario law. ${ }^{i 2}$ Under these circumstances the debtor must have perfected in Ontario to be assured of protection. However, if the litigation arises in province $Y$, where the chief place of business of the debtor is located, with all the other contacts including situs of the property, in Ontario, the problem becomes more complex. Under common law principles province $Y$ would look to Ontario law. But Ontario would decline jurisdiction because the chief place of business is in $Y$. The final result would therefore depend on the principle of renvoi as interpreted by the forum. ${ }^{73}$ Again, the advantages arising from all provinces having uniform legislation in this field are apparent.

Section 5 (3) provides that:

If a jurisdiction does not provide, by registration or recording in such jurisdiction, for perfection of a security interest of the kind referred to in subsections 1 and 2 , the security interest may be perfected by registration in Ontario.

Clearly the section is designed to apply to the perfection of security interests in collateral of the same nature to which subsections (1) and (2) are applicable. It is likewise clear that the subsection applies to security interests given by debtors whose chief place of business is located in a jurisdiction not having a law similar to the Act. If such a jurisdiction does not provide for perfecting an interest in intangibles and mobile equipment owned by a debtor whose chief place of business is located therein, perfection may be accomplished by registering in Ontario. This would always be the case with respect to all intangible and movable equipment where all contacts except the chief place of business are located in Ontario, unless the jurisdiction housing the chief place of business has a law corresponding to the Ontario Act. To illustrate the type of situation where registration in Ontario under such circumstances would be relevant, suppose the chief place of business is in province $Y$, which does not have the Act, and that all other contacts are in Ontario. Litigation arises in $Y$. The law of Ontario will be looked to but Ontario will refuse jurisdiction because of section 5(2). Province $Y$ will then return to its own law, which requires perfection under the law of the situs of the collateral. Since all contacts are in Ontario, perfection will be determined by records rule under s. 9-103 (1) of the Uniform Commercial Code. 
that law. Section 5(3) makes this permissible and in doing so says expressly what is already implicit in subsection (2).

The "chief place of business of a debtor" is not defined by the Act, but this ought not to lead to any confusion as to what is meant. The Official Comments to Article 9 define the term as "the place from which in fact the debtor manages the main part of his business operations." ${ }_{i 4}$ In some instances an interprovincial enterprise may raise a question as to which province contains the chief place of business, but this uncertainty may be resolved quite easily and inexpensively by registering in each province which has the Act where the business is carried on.

In stating the criterion for determining jurisdiction over collateral falling under section 5, the Act departs from Article 9, which adopts "the office where the assignor . . . keeps his records" in the case of accounts and contract rights, and "the chief place of business" only where mobile equipment is involved." Persuaded no doubt by American opinion, of which there is considerable, that there is little justification for drawing distinctions between accounts, contract rights, and general intangibles in the style of Article 9, the draftsmen amalgamated all three under one term: "intangibles." these distinctions should not be reintroduced in drafting a choice of law rule. But the fact is that as a matter of business practice there is generally no commonly agreed upon place for recording the existence of interests in certain types of collateral falling under the definition of "intangibles," book debts for example, and even if there were, there is no assurance that it would generally bear a reasonable relationship with the location of the debtor's place of business, an important consideration in selecting a rule for determining jurisdiction. It is therefore quite reasonable that the "place of records" criterion should be abandoned, as it is under the Act, and that "the chief place of business" be chosen for

74 U.C.C. s. 9-103 Official Comment 3. Similar phrases are common in Canadian jurisprudence. Compare, for example "principal place of business" as defined in the Bank Act, S.C. 1966-67, c. 87, s. 88 (k) (v): It "means... the place where according to the company's charter, memorandum of association or by-laws, the head office of the company in Canada is situated and in the case of any other company means the place at which civil process in the province or territory
in which the loans or advances will be made can be served upon the company." in which the loans or advances will be made can be served upon the company." "manages the main part of his business" this definition would not be acceptable in construing "chief place of business" under the Act. Compare the rule respecting the "head office" of a dominion company, R.S.C. 1952, c. 53, s. 21. And compare "head office" and "principal place of business" as used in the Model Conditional Sales Act, s. 4 (4). The domiciliary concept for registration of interests in intanglbles is not new either. For example, the Model Assignment of Book Debts Act (Model Act S. 5: R.S.O. 1960, c. 24, s. 4, as well as some of the other chattel security legislation) stipulates the place for registration variously as in the province of "the head office" or the "registered office" of a corporation and the "place of business' in the case of unincorporated assigmors.

75 U.C.C. ss. 9-103 (1) and (3).

70 It is regrettable that the term "general intangibles" or perhaps "pure intangibles" was not used in lieu of "intangibles" since the approach followed by the Act leads to some unnecessary confusion. The confusion arises because "intangibles" as used at common law covers a much broader territory than the definition given to it under the Act s. 1 ( $\mathrm{m}$ ), which excludes "chattel paper, documents of title, instruments or securities." The chlef difficulty arises simply from the constant necessity of qualifying the use of the word "intangibles" for the purpose of indicating whether it is being used in the sense in which it is generally used in pre-Act law or as defined under the Act For example, in discussing intangibles, chattel paper, documents of title, and securities, etc. are tangible collateral under the Act when under pre-Act law these items are usually though of as bing intanglble. The need for this cow these items are usually though of as being confusion, could be eliminated by using a more self-descriptive term. This suggests that words which are to be terms of art ought to be selected carefully and sparingly for use in the Act, if they already have a common usage in the law, particularly where there are alternatives avallable which are more self-descriptive. It is interesting to note that "intangibles" is not a term of art under Article 9. 
intangibles as well as mobile equipment. In following this approach the Act has avoided a problem which now prevails by virtue of the Article 9 dichotomy. ${ }^{77}$

\section{III.-CONCLUSION}

The basic issue in removal cases is which of two innocent parties should bear the loss (assuming the secured party may be classified as innocent even though it is he who makes the decision to create the nonpossessory security interest). A humanitarian and commercially expedient result would seem to call for the loss to fall on the party best able to bear it. Frequently, though not uniformly, this is the secured party-usually a financial institution which might well consider the potential loss through unauthorized removals and fraudulent dispositions as a business risk akin to that arising through shoplifting and other forms of theft. But it is the absence of consistency on this point (witness the fact that the real loser in an unauthorized disposition might be another institutional lender) that militates against a rule which would place the risk of loss on the secured party in all cases. Thus the Act makes a reasonable compromise in its situs rules by subordinating an out-of-province security interest to rights of various third parties arising after the expiration of the sixty-day temporary perfection period, or in denying a temporary perfection period altogether where the out-of-province security interest is unperfected at the original situs. In so providing the Act departs substantially from the law of those jurisdictions which provide that the registration period of the out-ofprovince interest does not begin to run until the secured party receives notice of the removal, but the rules of the Act provide for a more equitable result. In addition the Act brings rationality into the determination of priorities between conflicting security interests in collateral which, by virtue of its intangible nature, has no situs at all except in a purely metaphysical sense, or which is so ambulatory that a permanent situs is difficult if not impossible to establish. The latter innovation also represents a laudable improvement over pre-Act law and should commend itself to the various jurisdictions of a nation operating under a system which contemplates multiple filing units. Notwithstanding the minor imperfections of the choice of law provisions of the Act therefore, all Canadian jurisdictions would do well to give serious consideration to their adoption. 